\title{
Conditions d'implantation monastique en pays charentais
}

\section{Cécile Treffort}

\section{(2) OpenEdition \\ Journals}

Édition électronique

URL : http://journals.openedition.org/adlfi/1198

ISSN : 2114-0502

Éditeur

Ministère de la culture

Référence électronique

Cécile Treffort, "Conditions d'implantation monastique en pays charentais », ADLFI. Archéologie de la France - Informations [En ligne], Poitou-Charentes, mis en ligne le 01 mars 2008, consulté le 21 avril 2019. URL : http://journals.openedition.org/adlfi/1198

Ce document a été généré automatiquement le 21 avril 2019

(C) Ministère de la Culture et de la Communication, CNRS 


\title{
Conditions d'implantation monastique en pays charentais
}

\author{
Cécile Treffort
}

\section{Identifiant de l'opération archéologique : 204076}

Date de l'opération : 2001 - 2008 (PC)

Pour sa dernière année de fonctionnement, le PCR a privilégié deux optiques, à savoir le traitement des données acquises depuis 2001, date de sa création, et leur pérennisation. L'inventaire préliminaire des établissements religieux des deux départements de Charente et Charente-Maritime, réalisé commune par commune par le biais d'un dépouillement bibliographique et archivistique ainsi que de prospections sur le terrain, a été déposé au service régional de l'Archéologie sous sa forme papier (consultable sur demande auprès de la responsable du PCR); il a en outre fait l'objet d'un enregistrement partiel sur une base informatique, après analyse critique des données. D'autre part, les informations réunies lors d'opérations de terrain menées dans le cadre du PCR les années précédentes ont donné lieu, entre autres, à des reconstitutions en trois dimensions (notamment salle des malades de Surgères et salle des moines de Fontdouce) permettant d'appréhender de manière plus complète le phénomène monastique dans la région. Enfin, trois réunions, à Saint-Etienne, Paris et Poitiers, ont permis d'établir un rapprochement avec le CERCOR (Centre européen de recherche sur les congrégations et ordres religieux université de Saint-Etienne), qui prévoit la constitution d'une base nationale au sein de laquelle les sites monastiques charentais auront une place de choix.

TREFFORT, Cécile 
INDEX

Index géographique : Poitou-Charentes, Charente (16)

Index chronologique : Moyen Âge

operation Projet collectif de recherche (PCR)

Thèmes : archives, base de données, bibliographie, inventaire, monastère

\section{AUTEURS}

\section{CÉCILE TREFFORT}

SUP 